Special issue of the International Conference on Computational and Experimental Science and Engineering (ICCESEN 2014)

\title{
Numerical Analysis of Pulverised Coal Fired Boiler with Different Burner Geometries
}

\author{
B. GuREL*, O. IPEK, AND M. KAN \\ Mechanical Engineering, Isparta, Turkey
}

\begin{abstract}
Pulverized coal combustion is extensively used in utility boilers, industrial boilers, furnaces, kilns, and other energy conversion appliances. The effective utilization of pulverized coal is the main problem in study of combustion processes, particularly in burning low-grade coal. It is well known that the emission of nitrogen oxides $\left(\mathrm{NO}_{x}\right)$ during coal combustion is a main environmental problem. In this study, three different pulverised coal burner geometries for a pulverised coal fired boiler have been studied by numerical analysis. GLI-Tunçbilek coal was used as fuel. Threedimensional numerical analysis was carried out using Ansys Fluent code. Realizable $K-\varepsilon$ turbulence method, single rate devolatilization method, multiple char combustion method and second-order upwind discretization method were used during calculations. Coal particle diameter and coal mass flow rate were assumed to be $70 \mu \mathrm{m}$ and $378 \mathrm{~kg} / \mathrm{h}$ respectively.
\end{abstract}

DOI: 10.12693/APhysPolA.128.B-43

PACS: $44.15 .+\mathrm{a}$

\section{Introduction}

The optimization of the pulverized coal heater design and of process parameters is one of the basic factors which affects the quality of the production of the thermal energy and the efficiency of the thermal power plants. Although the burning efficiency of pulverized coal is $99 \%$, the $\mathrm{CO}, \mathrm{CO}_{2}$ and $\mathrm{NO}_{x}$ emissions are quite high. According to "The Industrialized Air Pollution Control Guide", corresponding to EU "Large Combustion Plant Directive", the maximum $\mathrm{NO}_{x}$ emission level is $800 \mathrm{mg} / \mathrm{N} \mathrm{m}^{3}$ (600 ppm) and maximum $\mathrm{CO}$ emission level is $1000 \mathrm{mg} / \mathrm{N} \mathrm{m}^{3}$. A few numerical and experimental studies of $\mathrm{NO}_{x}$ emission during combustion of pulverised coal are found in the literature. Edge et al. [1], carried out simulation of a boiler, burning the pulverized lignite, with a power of $350 \mathrm{MW}$. By optimizing the layout they achieved a reduction in $\mathrm{NO}_{x}$ emissions between $20-30 \%$. Kai et al. [2], in a study of a specially designed combustion chamber, burning of the pulverized coal in the oxidizer swirl flow of $\mathrm{O}_{2} / \mathrm{N}_{2} / \mathrm{CO}_{2}$ was investigated by changing the molar ratio of oxidizer components. A lot of studies of pulverised coal combustion in the literature are done for a particular burner, considering different boundary conditions. However, there are no studies of pulverised coal combustion which consider the same boundary conditions for different burners. In this study, numerical analysis of $378 \mathrm{~kg} / \mathrm{h}$ coal burning boiler is carried out using three different kinds of flow geometry.

\section{Numerical modelling}

Accurate modelling of pulverised fuel combustion is very chalenging. For air-fired combustion, with modern

*corresponding author; e-mail: barisgurel@sdu.edu.tr turbulence models and improved fuel combustion models, good predictions have been achieved [3, 4], although small inconsistencies still exist, related with the prediction of local temperatures and radiative heat transfer in the furnaces. The furnaces (Fig. 1) have been modelled in three dimensions using FLUENT, the commercial CFD software from ANSYS, version 14. FLUENT has been utilized for the numerical study of pulverized coal combustion in the past $[1,3,5]$ and proved to be efficient. For air-fired combustion, the Gli-Tunçbilek Turkish coals have been used. Gli-Tunçbilek coal contains 72.9 wt.\% C, 14.6 wt. \% O, 5 wt.\% N, 4.9 wt.\% S. In terms of approximate analysis the Gli-Tunçbilek coal consist of 35.6 wt.\% of fixed carbon, 14.3 wt.\% of volatile matter, $32 \mathrm{wt} . \%$ of ash and $13 \mathrm{wt} . \%$ of moisture.

\subsection{Boundary conditions}

In the analysis, the following boundary conditions have been used: (i) air mass flow rate $0.264 \mathrm{~kg} / \mathrm{s}$, temperature $300 \mathrm{~K}$, velocity $20 \mathrm{~m} / \mathrm{s}$, (ii) air mass flow rate $0.396 \mathrm{~kg} / \mathrm{s}$, temperature $300 \mathrm{~K}$, velocity $20 \mathrm{~m} / \mathrm{s}$, coal flow rate of $0.105 \mathrm{~kg} / \mathrm{s}$.

TABLE

Geometric properties of three different burners.

\begin{tabular}{c|c|c|c}
\hline \hline Burner & 1 & 2 & 3 \\
\hline Primary air diameter [mm] & 101 & 101 & 101 \\
Secondary air diameter[mm] & 163 & 163 & 163 \\
Secondary air swirler length [mm] & 35 & 35 & 35 \\
Secondary air swirler angle [mm] & $30^{\circ}$ & $45^{\circ}$ & $60^{\circ}$ \\
Number of secondary air swirler & 12 & 12 & 12 \\
Secondary air swirler thickness [mm] & 4.75 & 4.75 & 4.75
\end{tabular}

The geometric properties of three different burners are presented in Table. The furnace, shown in Fig. 1, is $10 \mathrm{~m}$ in length and $1.5 \mathrm{~m}$ in diameter. 


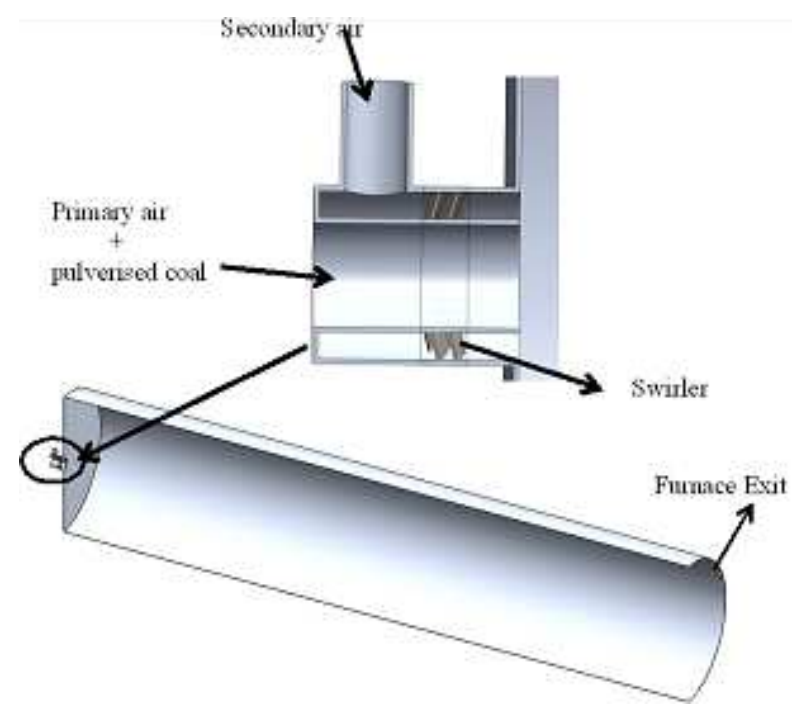

Fig. 1. Burners and test furnace geometry.

\subsection{Turbulence modelling}

In this study, the $K-\varepsilon$ turbulence model was used in numerical analysis. The turbulence kinetic energy, $K$ and its rate of dissipation, $\varepsilon$ have been obtained from the following equations for standard $K-\varepsilon$ model:

$$
\begin{aligned}
& \frac{\partial}{\partial t}(\rho k)+\frac{\partial}{\partial x_{i}}\left(\rho k u_{i}\right)=\frac{\partial}{\partial x_{j}}\left[\left(\mu+\frac{\mu_{t}}{\sigma_{k}}\right) \frac{\partial k}{\partial x_{j}}\right] \\
& \quad+G_{k}+G_{b}-\rho \varepsilon-Y_{M}+S_{k}, \\
& \frac{\partial}{\partial t}(\rho \varepsilon)+\frac{\partial}{\partial x_{i}}\left(\rho \varepsilon u_{i}\right)=\frac{\partial}{\partial x_{j}}\left[\left(\mu+\frac{\mu_{t}}{\sigma_{k}}\right) \frac{\partial \varepsilon}{\partial x_{j}}\right] \\
& \quad+C_{1 \varepsilon} \frac{\varepsilon}{k}\left(G_{k}+C_{3 \varepsilon} G_{b}\right)-C_{2 \varepsilon} \rho \frac{\varepsilon^{2}}{k}+S_{\varepsilon}, \\
& C_{1}=\max \left[0.43, \frac{\eta}{\eta+5}\right], \eta=S \frac{k}{\varepsilon}, S=\sqrt{2 S_{i j} S_{i j}} .
\end{aligned}
$$

In these equations $G_{k}$ represents the generation of turbulence kinetic energy due to the mean velocity gradients, $G_{b}$ is the generation of turbulence kinetic energy due to buoyancy, $Y_{M}$ represents the contribution of the fluctuating dilatation in compressible turbulence to the overall dissipation rate, $C_{2 \varepsilon}$ and $C_{1 \varepsilon}$ are constants. $\sigma_{k}$ and $\sigma_{\varepsilon}$ are the turbulent Prandtl numbers for $K$ and $\varepsilon$, respectively. $S_{k}$ and $S_{\varepsilon}$ are user-defined source terms.

\subsection{Radiation modelling}

The main advantave of the P1 model over the DO model is its low numerical cost. The P1 model showed low accuracy when complex geometries were involved. Because of this reason, the Discrete Ordinates (DO) method was selected for radiation modelling. Weighted sum of gray gases model $[4,6]$ was selected to calculate the fluid absorption coefficient. In addition, scattering function of 0.9 , has been used [3].

\subsection{Discrete phase modelling}

The trajectory of a discrete phase particle is predicted by integrating the force balance equation for the particle. The force balance condition equates the particle inertia with the forces acting on the particle, and can be written as:

$$
\frac{\mathrm{d} u_{p}}{\mathrm{~d} t}=F_{D}\left(u-u_{p}\right)+\frac{g_{x}\left(\rho_{p}-\rho\right)}{\rho_{p}}+F_{x},
$$

where $u_{p}$ is the particle velocity, $u$ is the fluid velocity in the current computational cell, $g_{x}$ is the gravitational acceleration, $F_{D}\left(u-u_{p}\right)$ is the drag force per unit particle mass, and $F_{x}$ is the additional fluid acceleration [7].

\subsection{Chemical process modelling}

Based on the study, the single rate devolatilization model, which gives good compromise between accuracy and hardware requirements $[3,4]$ was used in this work. Pre-exponential factor $(A)$ and the activation energy $(E)$ of the single rate devolatilization model were assumed to be $2.0 \times 10^{5}$ and $4.9 \times 10^{7}(\mathrm{~J} / \mathrm{kg} \mathrm{mol})$ [8] In this study the multiple char reactions model has been used. Multiple surface reactions, volumetric and particle surface reactions, pre-exponential factors, activation energies and temperature exponent $(\beta)$, have been taken from [8]. The turbulence-chemistry interaction has been modelled using FR-ED model (finite-rate/eddydissipation). Three gas reactions and three char reactions have been considered.

\section{6. $\mathrm{NO}_{x}$ modelling}

The developed sub-model of $\mathrm{NO}_{x}$ formation/destruction is described in [9]. The $\mathrm{NO}_{x}$ sub-model consists of reactions of fuel NO formation and depletion [10]. Transport equation of the $\mathrm{NO}_{x}$ modelling are presented below

$$
\begin{aligned}
& \frac{\partial}{\partial x_{j}}\left(\rho U_{j} X_{\mathrm{NO}}\right)=\frac{\partial}{\partial x_{j}}\left(\Gamma_{\mathrm{NO}} \frac{\partial X_{\mathrm{NO}}}{\partial x_{j}}\right) \\
& +S_{\mathrm{NO}} \frac{\partial}{\partial x_{j}}\left(\rho U_{j} X_{\mathrm{HCN}}\right)+S_{\mathrm{NO}} \frac{\partial}{\partial x_{j}}\left(\rho U_{j} X_{\mathrm{NH}_{3}}\right)= \\
& \frac{\partial}{\partial x_{j}}\left(\Gamma_{\mathrm{HCN}} \frac{\partial X_{\mathrm{HCN}}}{\partial x_{j}}\right)+\frac{\partial}{\partial x_{j}}\left(\Gamma_{\mathrm{NH}_{3}} \frac{\partial X_{\mathrm{NH}_{3}}}{\partial x_{j}}\right) \\
& +S_{\mathrm{HCN}}+S_{\mathrm{NH}_{3}} .
\end{aligned}
$$

\section{Results and discussions}

As shown in Fig. 2 the mean temperatures at the outlet of the furnace for the three considered cases are $1438 \mathrm{~K}$, $1443 \mathrm{~K}$ and $1396 \mathrm{~K}$ respectively. $\mathrm{NO}_{x}$ emission was $227 \mathrm{ppm}$ for the first considered burner, $766 \mathrm{ppm}$ for the second burner and $689 \mathrm{ppm}$ for the third. Char combustion efficiency in the same cases was $99 \%, 66 \%$ and $40 \%$. The results show, that minimum $\mathrm{NO}_{x}$ emission and maximum char combustion efficiency was achieved with the first burner. 

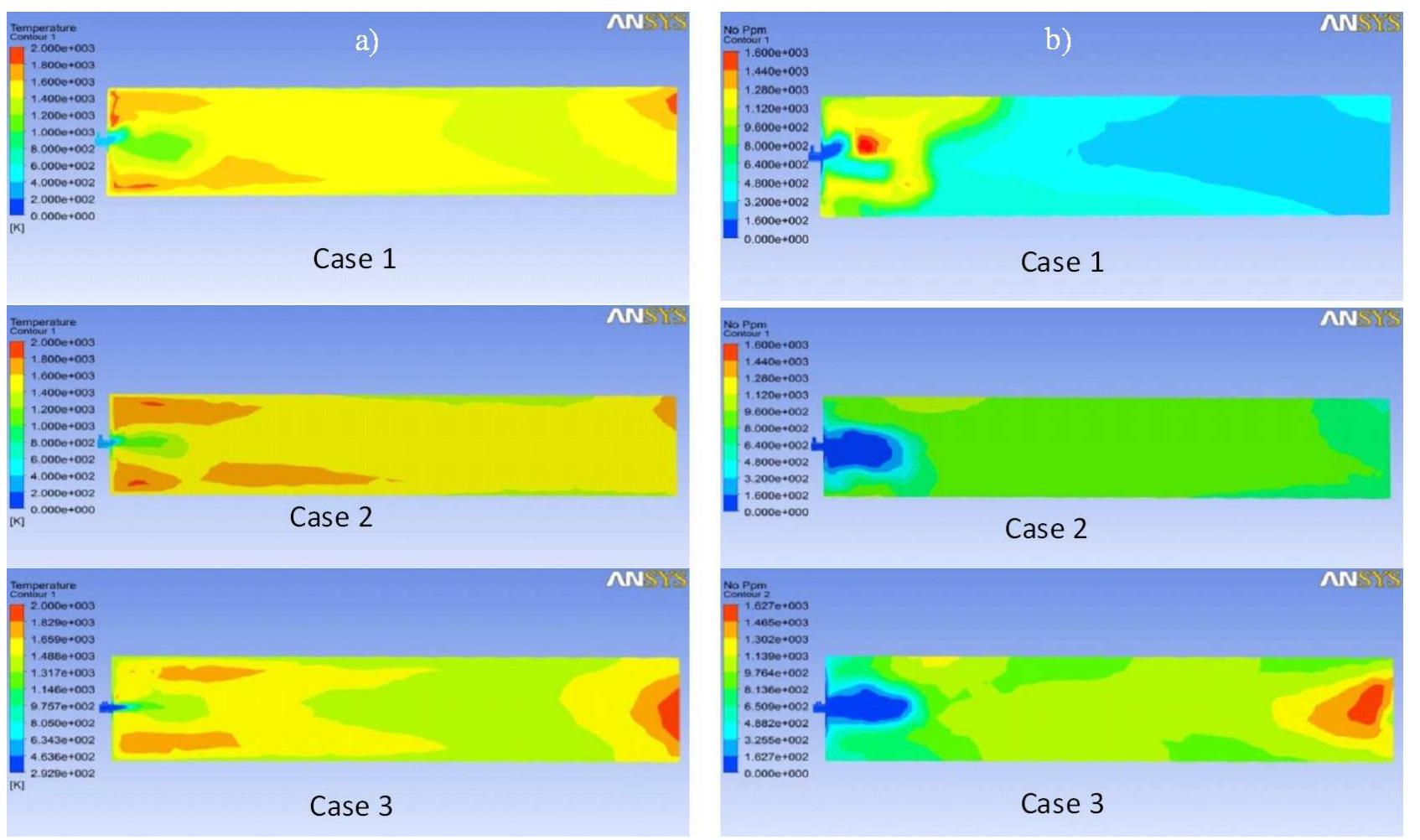

Fig. 2. Temperature (a) and $\mathrm{NO}_{x}$ (b) distribution in the furnace for the three considered burners.

\section{Conclusions}

The study has been focused on the combustion analysis in the three different burners. Air-staged and fuelstaged combustion of the the pulverised coal is used for the reduction of $\mathrm{NO}_{x}$ emission. There are a lot of numerical studies of air-staged and fuel-staged combustion in the literature. However, there is no numerical analysis, comparing different geometries of pulverised coal burner. In this study three burners with different angles of secondary air swirler were investigated. Secondary air swirler with $30^{\circ}$ angle was found to be more productive, by having a higher combustion efficiency and lower $\mathrm{NO}_{x}$ emission.

\section{References}

[1] P. Edge, S. Gubba, L. Ma, R. Porter, M. Pourkashanian, A. Williams, Proc. Combust. Inst. 33, 2709 (2011).

[2] C. Kai, L. Bing, W. Yuxin, Y. Hairui, L. Junfu, Z. Hai, Chinese J. Chem. Eng. 22, 193 (2014).
[3] R. Backreedy, L. Fletcher, L. Ma, M. Pourkashanian, A. Williams, Combust. Sci. Technol. 178, 763 (2006).

[4] M. Gharebaghi, R.M.A. Irons, L. Ma, M. Pourkashanian, A. Pranzitelli, Int. J. Greenhouse Gas Control 5S, S100 (2011).

[5] D. Toporov, P. Bocian, P. Heil, A. Kellermann, H. Stadler, S. Tschunko, M. Förster, R. Kneer, Combust. Flame 155, 605 (2008).

[6] R. Jovanovic, B. Rasuo, P. Stefanovic, D. Cvetinovic, B. Swiatkowski, Int. J. Heat Mass Tran. 58, 654 (2013).

[7] ANSYS FLUENT 14 User's Guide, Fluent Inc., 2013, USA.

[8] P. Warzecha, A. Boguslawski, Energy 66, 732 (2014).

[9] S. Belosevic, V. Beljanski, I. Tomanovic, N. Crnomarkovic, D. Tucakovic, T. Zivanovic, Energy Fuels 26, 425 (2012).

[10] G.G. De Soete, Proc. Combust. Inst. 23, 1257 (1991). 